\title{
Pinjaman Online di Masa Pandemi Covid-19 bagi Masyarakat Aceh
}

\author{
Asmah Savitri ${ }^{1}$ Angga Syahputra ${ }^{2 *}$ Husna Hayati $^{3}$ dan Heny Rofizar ${ }^{4}$ \\ 1,2,3,4 Fakultas Ekonomi dan Bisnis Islam - IAIN Lhokseumawe \\ Email Corespondent : anggasyahputra@iainlhokseumawe.ac.id
}

\begin{abstract}
Online loans are digital financial service innovations that are very touching to people in need, especially during the Covid-19 pandemic. September 2020 data shows online loans have disbursed Rp. 417.6 billion to the people of Aceh. So that research on the impact of pinjol during the pandemic for the people of Aceh is important. This study uses a qualitative research type by using a literature study type of research. The results of this study indicate that online loans have a good impact in helping the difficulty of funds for the people of Aceh. However, this study also found that online loans have negative impacts that must be watched out for, including: the rise of illegal online loans, high interest rates and acts of terror and defamation that stalk users of this service.
\end{abstract}

Keywords : online loans, covid-19, aceh community.

\begin{abstract}
Abstrak: Pinjaman online merupakan inovasi layanan keuangan secara digital yang sangat menyentuh pada masyarakat yang membutuhkan, apalagi di masa pandemi Covid-19. Data September 2020 menunjukkan pinjaman online telah mengucurkan dana sebesar Rp. 417.6 miliar kepada masyarakat Aceh. Sehingga penelitian tentang dampak pinjol di masa pandemi bagi masyarakat Aceh penting dilakukan. Penelitian ini menggunakan jenis penelitian kualitatif dengan menggunakan jenis penelitian literature study. Hasil penelitian ini menunjukkan bahwa pinjaman online memiliki dampak yang baik guna membantu kesulitan dana bagi masyarakat Aceh. Namun, penelitian ini juga menemukan bahwa pinjaman online memiliki dampak negatif yang harus diwaspadai, antara lain: maraknya pinjaman online ilegal, suku bunga yang tinggi serta aksi teror dan pencemaran nama baik yang mengintai pengguna layanan ini.
\end{abstract}

Keywords : pinjaman online, covid-19, masyarakat aceh. 


\section{PENDAHULUAN}

Pandemi Covid-19 memiliki dampak yang begitu parah pada sektor ekonomi di berbagai negara dan wilayah, termasuk di Indonesia dan Provinsi Aceh. Hal ini diperparah lagi dengan kebijakan berbagai negara dalam memerangi wabah ini yang menyebabkan ekonomi masyarakat semakin parah (Syahputra, Armayani, \& Syahmalluddin, 2020). Pembatasan aktivitas akibat pandemi Covid-19 juga telah menimbulkan kerugian ekonomi secara nasional (Hadiwardoyo, 2020).

Pandemi Covid-19 telah membawa resiko yang sangat buruk bagi perekonomian nasional (Nasution, Erlina, \& Muda, 2020). Indonesia sendiri telah melakukan berbagai langkah guna mengurangi dampak pandemi Covid-19 bagi masyarakat. Beberapa langkah yang telah dilakukan seperti penurunan BI 7-Day Reverse Repo Rate sebesar 25 bps menjadi $4.75 \%$, suku bunga Deposit Facility menjadi $4 \%$ dan suku bunga Landing Facility menjadi $5.50 \%$. Langkah ini dilakukan untuk memberikan stimulus pertumbuhan ekonomi ditengah pandemi Covid-19. Langkah ini juga diambil agar menjaga inflasi tetap terkendali dan stabilitas eksternal dapat terus dijaga (Wibowo, 2017).

Dunia usaha sendiri saat ini sudah mulai kelimpungan. Proses input dan output ekonomi banyak yang macet. Banyak perusahaan yang menutup pabriknya akibat daya beli masyarakat yang terus menurun. PHK juga terjadi di berbagai sektor dan di berbagai daerah. Masyarakat kecil pelaku UMKM, petani, nelayan dan buruh yang mengharapkan pendapatan harian bahkan mengalami dampak yang lebih parah. Hal ini tentunya membuat kondisi rentan pangan dan krisisi kelaparan.

Ekonomi Aceh sendiri sangat bergantung pada Sumber Daya Alam, dari sektor agro dan perikanan. Kondisi ekonomi Aceh sangat terpengaruh dinamika pasar di luar Aceh atau supply chain dalam kondisi pandemi akan membuat ekonomi Aceh dan masyarakatnya terdampak (Nurchalish, 2020).

Badan Pusat Statistik (BPS) mencatat pertumbuhan ekonomi Aceh pada triwulan II tahun 2021 sebesar 2,56\%. Pertumbuhan itu disebut paling rendah bila dibandingkan provinsi lain di Sumatera. Bila dilihat dari sumber pertumbuhan ekonomi Aceh triwulan II-2021 y-on-y, sumber pertumbuhan tertinggi berasal dari lapangan usaha transportasi dan pergudangan sebesar 2,31\%, diikuti perdagangan besar dan eceran sebesar $1,24 \%$ serta administrasi pemerintahan, pertahanan dan jaminan sosial wajib sebesar 1,13\% (Setyadi, 2021).
Dari data BPS disebutkan bahwa angka pengangguran terbuka di Aceh naik dari 5.42\% pada semester I - 2020 menjadi $6.59 \%$ di semester II-2020. Kondisi pengangguran yang terus meningkat ini tentu akan berdampak pada tingkat kemiskinan yang akan meningkat pula. penduduk miskin Aceh pada September 2020 tercatat sebesar $15,43 \%$, atau naik 0,44 poin dibanding Maret 2020 yang sebesar 14,99 \%. Sedangkan jumlah penduduk miskin Aceh pada September 2020 sebanyak 833,91 ribu orang, bertambah 19 ribu orang dibanding Maret 2020 sebesar 814, 91 ribu orang (Republika, 2021).

Saat ini, guna membantu masyarakat keluar dari kesulitan ekonomi, banyak jasa Pinjaman Online (Pinjol) yang menawarkan pinjaman dengan bunga rendah. Pinjol ini dapat dengan mudah diakses hanya bermodalkan Kartu Tanda Penduduk (KTP) dan telepon seluler. Di masa pandemi saat ini, pinjol dianggap penolong bagi masyarakat, karena mampu memberikan dana untuk memenuhi kebutuhan harian dengan syarat yang mudah. Dengan berbagai kemudahan yang ada pada pinjol, diharapkan ekonomi masyarakat akan tumbuh (Santi, 2019).

Di Aceh sendiri per September 2020 tercatat pengguna jasa pinjol mencapai Rp. 417.6 miliar. Namun di sisi lain, banyak juga masyarakat Aceh yang terjebak akibat penggunaan jasa pinjaman online ini (Nurhadi, 2020). Untuk itu penelitian ini akan memaparkan bagaimana dampak pinjaman online di masa pandemi Covid-19 ini bagi masyarakat Aceh.

\section{TINJAUAN PUSTAKA}

\section{Pengaruh Pinjaman Online pada Masyarakat}

Pinjaman online merupakan layanan keuangan bagi masyarakat, hasil dari kemajuan teknologi dalam perekonomian nasional. Layanan ini diharapkan dapat meningkatkan kesejahteraan rakyat dengan perputaran ekonomi yang terus berjalan (Wahyuni \& Turisno, 2019). Tumbuh pesatnya pinjol di negeri ini juga disebabkan potensi masyarakat Indonesia yang cukup besar jumlah penduduknya, ditambah kondisi pandemi saat ini yang menyulitkan banyak ekonomi masyarakat.

Pinjaman online adalah bagian dari pengembangan financial technology (fintech), dimana hal ini merupakan bagian dari penggunaan teknologi pada sistem keuangan yang menghasilkan produk, layanan dan teknologi dan atau model bisnis baru yang dapat berdampak pada sistem stabilitas moneter, stabilitas sistem keuangan, efesiensi, kelancaran, keamanan dan keandalan sistem pembayaran (Supriyanto \& Ismawati, 2019). 
Pinjaman online juga terbukti dapat memberikan kemudahan kepada penggunanya, baik dari akses pada layanan, syarat dan kecepatan. Pinjol juga menjadi jalan keluar secara cepat bagi masyarakat yang membutuhkan dana secara cepat untuk berbagai keperluan tanpa harus datang pada institusi keuangan dengan membawa berbagai syarat bahkan agunan (Panginan \& Irwansyah, 2020).

\section{Covid-19 bagi Ekonomi Masyarakat Aceh}

Pandemi Covid-19 adalah situasi yang belum pernah terbayang bagi masyarakat Aceh bahkan masyarakat di seluruh wilayah pada umumnya. Virus ini berawal dari ditemukannya kasus pneumonia pertama kali yang dilaporkan di Kota Wuhan, Provinsi Hubei, China. Dari sampel yang diteliti menunjukkan kasus coronavirus baru. Awalnya penyakit ini dinamakan 2019 Novel Coronavirus (2019-nCov). Hingga kemudian pada 11 Pebruari 2020, World Health Organization (WHO) merubahnya menjadi Coronavirus Disease (Covid-19) yang disebabkan oleh virus Severe Acute Respiratory Syndrome Coronavirus-2 (SARS-CoV-2) (Susilo, et al., 2020).

Penyebaran Covid-19 berdampak pada melambatnya pertumbuhan ekonomi di Indonesia termasuk Provinsi Aceh. Dampak yang dirasakan melalui jalur perdagangan (ekspor dan pariwisata) dan investasi. Apalagi ketika negara menerapkan kebijakan lockdown/PSBB/PPKM, maka akan berdampak pada perekonomian, baik di dalam negeri sendiri maupun di negara lain. Pembatasan aktifitas masyarakat akan memperlambat kegiatan ekonomi, menurunkan produktivitas, menurunkan permintaan (konsumsi, ekspor jasa, impor jasa, investasi, ekspor barang dan impor barang) dan juga akan berdampak langsung pada Produk Domestik Bruto (PDB) (Aliah, 2020).

Terbatasnya berbagai aktifitas masyarakat karena aturan yang ditetapkan pemerintah dalam melindungi warganya memiliki dampak yang begitu besar bagi masyarakat. Bahkan belanja online yang dianggap menjadi salah satu alternatif memudahkan kegiatan masyarakat juga terhambat karena aturan yang ada dan sumber daya manusia yang terbatas (Mohsin, Hongzhen, \& Hossein, 2021).

Masyarakat Aceh yang merupakan bagian dari komunitas masyarakat dunia juga begitu merasakan dampak pandemi Covid-19. Bahkan beberapa peneliti menyimpulkan dampak ini akan tetap ada pasca pandemi Covid-19. Penghasilan Aceh yang notabanenya berasal dari agraria dan laut yang terhubung dengan dunia luar, tentu turut merasakan dampak Covid-19. Jumlah wisatawan yang menurun drastis ke Aceh juga turut berdampak pada berbagai sektor seperti pariwisata, halal food, fashion, hotel dan lain sebagainya (Presilawati, Erlinda, \& Muhammad, 2020).

Tidak hanya itu, sektor UMKM juga turut terdampak akibat wabah Covid-19 ini. Belum lagi meningkatnya pengangguran serta biaya pendidikan yang semakin membebani masyarakat akibat biaya kuota internet dan fasilitas smartphone. Dunia usaha yang kelimpungan akibat pandemi dan kebijakan yang dikeluarkan pemerintah turut berdampak pada pekerja di seluruh sektor yang ada, dimana pada akhirnya berpengaruh pada kondisi ekonomi yang stagnan bahkan menurun (Husna, 2020).

\section{METODE PENELITIAN}

Penelitian ini menggunakan jenis penelitian kualitatif, dimana data yang didapatkan akan dideskripsikan dalam hasil penelitian. Dengan menggunakan data yang relevan, maka hasil penelitian ini akan diinterpretasikan melalui hasil yang valid. Model penelitian ini adalah literature review, dimana temuan dan bahan penelitian yang diperoleh akan dijadikan landasan dalam kegiatan penelitian ini.

Dalam menyelesaikan permasalahan yang ada, peneliti menggunakan jenis data sekunder yang didapat dari berbagai sumber, seperti: buku, artikel, jurnal, prosiding maupun informasi akurat dari website-website terpercaya dan relevan dengan penelitian ini, sehingga pada akhirnya mampu menjawab permasalahan yang ada.

\section{HASIL DAN PEMBAHASAN}

\section{Kemudahan Pinjaman Online bagi Masyarakat Aceh}

Era digital 4.0 ditandai dengan masuknya digitalisasi dalam aktivitas kehidupan masyarakat. Hal yang paling sederhana yang dapat dilihat dari perubahan ini adalah maraknya penggunaan smart phone di kalangan masyarakat. Dengan penggunaan smart phone ini, berbagai aktifitas penting saat ini dapat dilakukan melalui one touch, termasuk aktivitas keuangan.

Pinjaman online merupakan produk yang dikeluarkan lembaga keuangan nonbank yang saat ini marak di masyarakat. Pinjol merupakan aktivitas keuangan produk dari kemajuan teknologi di era digital 4.0. Pinjol adalah bagian dari inovasi di sektor keuangan atau sering disebut juga fintech. Syarat yang begitu mudah untuk mendapatkan akses pinjaman keuangan, membuat berbagai lapisan masyarakat dapat terbantu dengan modal 
segar dari lembaga penyedia, termasuk di kalangan mahasiswa sekalipun. Bahkan, dengan kemudahan akses pada pinjaman online sering kali pinjol dianggap "kartu kredit" bagi mahasiswa (Sihombing, Suryanto, Mahameru, Setiawan, \& Marsella, 2019).

Pinjaman online adalah inovasi keuangan yang mengikuti perkembangan zaman. Akses pada kredit adalah sumber kehidupan bisnis dan pertumbuhan ekonomi. Hal ini merupakan bagian dari upaya memulihkan ekonomi dan memastikan masyarakat mendapatkan akses keuangan untuk menjalankan usahanya. Tanpa kredit, pengusaha dan masyarakat tidak dapat menempatkan ide-ide inovatif menjadi sebuah tindakan (White House National Economic Council, 2012).

Kemajuan teknologi dan ketersediaan data mengubah cara konsumen dan bisnis kecil mengamankan pembiayaan. Dengan memanfaatkan perkembangan ini, pemberi pinjaman pasar online menawarkan kredit lebih cepat kepada konsumen dan usaha kecil. Selama sepuluh tahun terakhir, perusahaan pinjaman pasar online telah berevolusi dari platform yang menghubungkan peminjam individu dengan pemberi pinjaman individu, ke jaringan canggih yang menampilkan investor institusi, kemitraan institusi keuangan, pinjaman langsung, dan transaksi sekuritisasi (US DEPARTMENT OF THE TREASURY, 2016).

Pinjaman online adalah aplikasi yang disediakan pihak penyedia dana berdasarkan modal utama, yaitu kepercayaan (Wang, 2015). Di era ini, internet dan teknologi terus berkembang dari waktu ke waktu. Perkembangan teknologi mendorong industri untuk terus berinovasi dan beradaptasi dengan kondisi saat ini. Semakin meluas perkembangan teknologi dalam memudahkan masyarakat untuk melakukan berbagai aktivitas sehari-hari, termasuk di bidang keuangan. Munculnya teknologi keuangan di sektor finance tentunya akan memberikan kemudahan untuk semua jenis transaksi, termasuk pinjaman.

Pinjaman atau kredit adalah kepercayaan dari pemilik dana untuk membayar sejumlah dana dengan harapan pengembalian di masa depan (Suiter \& Thomas, 1938). Jika suatu perusahaan mendapatkan pendanaan dalam bentuk pinjaman, beberapa dana yang dipinjamkan oleh lembaga keuangan, dan perusahaan wajib mengembalikannya dalam waktu yang telah disepakati jangka waktu melalui angsuran, termasuk pokok dan bunga pinjaman (Kurniawan \& Wijaya, 2020).

Di Aceh sendiri, masyarakat sudah banyak yang mengetahui tentang keberadaan pinjaman online. Bermodalkan KTP dan rekening bank, masyarakat umumnya dapat mencairkan dana diangka jutaan rupiah. Kemudahan syarat ini cukup membantu masyarakat Aceh, apalagi pinjol tidak memerlukan agunan atau jaminan atas sejumlah dana yang dipinjam. Bahkan, koperasi yang berada pada beberapa daerah di Aceh tengah gencar saat ini merubah sistem pinjamannya berbasis online demi mengikuti trend yang ada (Ikhsan, 2021).

Kian diminatinya pinjaman online bagi masyarakat Aceh juga ditunjukkan dengan tingginya jumlah pinjaman masyarakat Aceh mencapai Rp. 417.6 miliar per September 2020 (Dadang Heryanto, 2020). Selain kebutuhan dana yang meningkat di era pandemi, sulitnya akses pendanaan ke bank bagi sebagian masyarakat dan pelaku UMK menjadikan pinjol sebagai alternatif masyarakat Aceh mengatasi kendala keuangan. Masyarakat kecil juga dapat lebih merasakan pinjaman kredit dengan hadirnya pinjol, dimana dulunya layanan kredit memerlukan persyaratan yang panjang, eksekusi yang memakan hari dan jaminan bagi pihak lembaga perbankan (Safitri, 2019).

\section{Bahaya Pinjaman Online}

Dalam aturan main pinjol, nasabah harus membayar sesuai waktu dan perjanjian. Jika nasabah membayar sesuai kesepakatan, maka tidak ada penagihan, yang ada hanya pengingat saja. Penagihan terjadi ketika komitmen pembayaran tidak terealisasi. Biasanya perusahaan penyedia layanan akan memberikan wewenang kepada debt collector untuk menagih pinjaman terhadap pengguna layanan (Embu, Faqir, Ronald, \& Sari, 2021).

Kemudahan pinjaman online melalui perkembangan teknologi memang membuat hidup lebih praktis dan efektif. Hanya saja pinjol membuat orang merasa ketagihan dengan kemudahan yang ditawarkannya. Dengan kemudahan teknologi, penyedia jasa juga akan mudah melakukan penagihan dengan cara yang kurang menyenangkan. Hal ini disebabkan penyedia jasa dapat mengakses lokasi pengguna, kontak telepon, melakukan dan mengelola panggilan telepon pengguna, mengirim dan mengakses sms, akses pada galeri foto, media dan file lain dalam perangkat ponsel yang seyogianya merupakan privasi pengguna layanan (Hirdianto, 2021). Beberapa bahaya yang mengincar pengguna layanan ini antara lain sebagai berikut.

Pertama, banyaknya pinjaman online ilegal. Dengan munculnya pinjaman melalui teknologi keuangan (fintech), maka keuangan konvensional mulai tergeser. Perkembangan sektor keuangan yang semakin maju menyebabkan kemajuan dalam 
hal meminjam uang. Namun, tidak semua perusahaan keuangan yang menerapkan fintech telah terdaftar. Otoritas Jasa Keuangan (OJK) mengungkapkan sampai dengan 4 Mei 2021 terdapat 138 fintech lending (pinjol) berlisensi/terdaftar resmi di OJK (Otoritas Jasa Keuangan, 2021).

Per Juli 2021 terdapat 3.365 pinjaman online ilegal (Satgas Waspada Investasi, 2021) yang telah diblokir oleh OJK, jumlah yang tertaut jauh dengan pinjol yang memiliki izin resmi. Dari jumlah tersebut, mayoritas pinjaman online ilegal berasal dari developer China. Dari mesin pencarian Google, platform tersebut dapat dengan mudah ditemukan pada aplikasi di Play Store dan App Store. Banyaknya layanan pinjaman online dari China yang masuk ke Indonesia kemungkinan disebabkan oleh adanya pengetatan peraturan di China. Namun, OJK juga belum dapat memastikan perusahaan tersebut bergerak di bidang apa dan seberapa banyak jumlah nasabahnya. Hal ini dikarenakan OJK tidak memiliki data resmi dan tidak dapat mendeteksi perusahaan yang namanya tidak terdaftar di OJK (Budiyanti, 2019).

Pinjaman online biasanya memiliki bunga yang sangat tinggi namun akses mendapatkannya sangat mudah. Selain itu, pinjol ilegal biasanya sering berganti nama, namun bunga pinjaman terus bertambah. Penagihan tidak hanya kepada pengguna layanan, namun juga kepada kontak darurat melalui pengancaman dan mencemarkan nama baik. Hal ini bahkan diikuti dengan penyalahgunaan data dengan penyebaran data pribadi kepada pihak lain yang diindikasikan digunakan untuk meminjam dana pada aplikasi pinjol lainnya. Hal lain yang mengintai dari pinjol ilegal adalah tidak terhapusnya hutang walaupun peminjam telah melunasinya (Salvasani \& Kholil, 2020).

Beberapa faktor yang menyebabkan maraknya pinjol ilegal adalah tidak adanya aturan terkait besaran suku bunga, tidak maksimalnya aturan hukum terhadap pinjol ilegal, tidak adanya ketentuan pidana bagi pinjol ilegal, sulitnya pengawasan terhadap pinjol ilegal, literasi masyarakat yang masih minim terkait pinjol dan berbagai produk fintech, tingginya minat masyarakat dan kemudahan terhadap akses aplikasi pinjol (Santi, Budiharto, \& Saptono, 2017).

Penegakan aturan yang melibatkan pelanggaran perusahaan pinjol ilegal juga masih belum optimal. Ada beberapa alasan untuk masalah tersebut, yaitu sebagian besar masyarakat belum melaporkan pelanggaran hak-hak mereka ke OJK. Kebanyakan orang tidak memiliki informasi yang cukup mengenai institusi yang bertanggungjawab atas kasus tersebut. Juga, ada faktor lain seperti kurangnya sosialisasi instansi terkait untuk mengidentifikasi pinjol ilegal (melalui pendaftaran dan izin di OJK), yang membatasi kesadaran masyarakat. Oleh karena itu, masyarakat sering menggunakan layanan pinjaman online ilegal daripada layanan berlisensi. Meskipun perusahaan pinjol ilegal yang tidak berlisensi memiliki tingkat resiko yang lebih tinggi melanggar hak konsumen pengguna layanan, seperti penyalahgunaan data pribadi dan pengumpulan pembayaran melalui intimidasi (Budiman, Rahayu, \& Jauhari, 2020).

Kedua, suku bunga yang lebih tinggi. Dengan proses mudah dan cepat untuk mendapatkan pinjaman, pinjaman online dinilai lebih bersahabat dengan UMKM dan masyarakat dibanding bank, namun umumnya pinjol memiliki suku bunga yang lebih tinggi dari lembaga keuangan konvensional yang ada (Samudro \& Risha, 2021).

Bunga dan denda yang dikenakan mencapai 1 sampai $4 \%$ per hari, ditambah biaya tambahan sebesar $40 \%$ dari nilai pinjaman. Jangka waktu pelunasan juga singkat, tidak sesuai kesepakatan, melakukan penagihan tidak beretika seperti teror, intimidasi dan pelecehan, serta tidak memiliki layanan pengaduan maupun identitas kantor yang jelas (RRI, 2021). Bunga yang tinggi tentu akan menambah beban masyarakat Aceh, apalagi di tengah kondisi pandemi saat ini, masyarakat dihadapkan dengan berbagai ketidakpastian.

Bunga dan denda yang besar pada pinjaman online merupakan akibat literasi masyarakat yang rendah dan keengganan untuk memahami perjanjian pada aplikasi pinjaman online, sehingga pada saat melakukan transaksi kredit, masyarakat sebagai peminjam sering tidak melihat secara detail isi dari ketentuan atau perjanjian kredit. Hal tersebut menyebabkan masyarakat terjerat dengan bunga yang sangat tinggi. Komisi atau bunga dari pinjaman online ilegal rata-rata mencapai lebih dari $40 \%$ dari utang pokok ditambah dengan denda Rp50 ribu per hari (Budiyanti, 2019).

Ketiga, teror dan pencemaran nama baik. Akses mudah dan cepat dari aplikasi ponsel membuat masyarakat tergiur pinjol di tengah berbagai kebutuhan hidup. Hal ini semakin diperparah dengan rendahnya pemahaman masyarakat terhadap pinjol, sehingga data pribadi sangat rentan untuk dicuri hingga penagihan yang dilakukan secara intimidatif sangat rentan (Asti, 2020). Beberapa kasus bahkan dalam jangka waktu seminggu peminjaman, belum sampai seminggu sudah diteror dengan ancaman sampai anak pengguna 
layanan akan dicelakai. Masyarakat pun akhirnya gali lubang tutup lubang untuk menutupi utang pada pinjol yang satu dengan meminjam uang ke pinjaman online lainnya.

Selain kasus di atas, ada berbagai macam tindakan teror dan pencemaran nama baik yang dilakukan oleh pinjaman online. Penagih bahkan tidak segan menebar fitnah agar peminjam dana membayar hutangnya. Terbaru, penyedia layanan memfitnah nasabah pinjol menjadi seorang pengedar narkoba sehingga pihak kepolisian ikut turun tangan (Aceh Standar, 2021). Teror dan pencemaran nama baik yang dilakukan pinjol bukanlah hal yang sederhana. Dampak psikologis yang ditinggalkan akan sangat mempengaruhi pribadi pengguna layanan. Bahkan akibat teror dan pencemaran nama baik, pinjaman online telah memakan korban jiwa (Harian Aceh, 2021). Teror dan pencemaran nama baik ini juga semakin berat dirasa masyarakat Aceh di tengah himpitan ekonomi pada masa pandemi Covid-19. Solusinya, edukasi dan literasi ke masyarakat, sebab pinjaman online ini masalahnya ada di hulu, pengetahuan masyarakat yang kurang (Harian Aceh, 2021).

\section{PENUTUP}

\section{Kesimpulan}

Pinjaman online ibarat sebuat pisau yang memiliki dua mata. Pada satu sisi pinjaman online memiliki dampak yang baik karena dapat membantu kebutuhan masyarakat dengan cepat, bahkan di wilayah Aceh saja per September 2020 telah disalurkan Rp. 417.6 miliar dana bagi masyarakat. Namun pada sisi lainnya, pinjaman online dapat menambah masalah bagi pengguna layanannya, seperti maraknya pinjaman online ilegal, suku bunga yang tinggi dan teror hingga pencemaran nama baik pengguna layanan. Untuk itu dibutuhkan literasi masyarakat Aceh tentang pinjaman online sehingga masyarakat tidak terjebak pada dampak buruk yang ada pada pinjol. Selain itu, dibutuhkan regulasi yang jelas dan pengawasan yang ketat oleh OJK agar masyarakat terlindungi, terutama terkait privasi yang dapat mengganggu aspek kehidupan dan psikologi masyarakat, apalagi ditengah himpitan ekonomi pada masa pandemi Covid-19.

\section{Saran}

Dibutuhkan penelitian yang lebih komprehensif tentang dampak pinjaman online di masa pandemi Covid-19 bagi masyarakat Aceh dengan melakukan sebaran angket dan wawancara kepada sampel penelitian, sehingga data yang didapat lebih akurat dan dapat dijadikan referensi bagi pengguna layanan. 


\section{REFERENSI}

Aceh Standar. (2021). Korban Pinjol Dituduh Jadi Bandar Narkoba agar Bayar Utang. Retrieved Agustus 30, 2021, from https://www.acehstandar.com/news/korban-pinjol-dituduh-jadi-bandar-narkobaagar-bayar-utang/index.html

Aliah, N. (2020). The Impact of Covid 19 on National Economic Growth. International Proceeding of Law \& Economic (pp. 62-68). Medan: Universitas Panca Budi.

Asti, N. P. (2020). Upaya Hukum Otoritas Jasa Keuangan dalam Mengatasi Layanan Pinjaman Online Ilegal. Acta Comitas, 5(1), 111-122, DOI: 10.24843/AC.2020.v05.i01.p10.

Budiman, I., Rahayu, S. W., \& Jauhari, I. (2020). The Financial Services Authority Supervision To Financial Technology Peer-To-Peer Lending In Relation To Consumer Rights In Aceh. IOSR Journal of Humanities And Social Science (IOSR-JHSS), 25(7), 22-26, DOI: 10.9790/08372507132226 .

Budiyanti, E. (2019). Upaya Mengatasi Layanan Pinjaman Online Ilegal. Jurnal Pusat Penelitian Badan Keahlian DPR RI, XI(4), 19-24.

Dadang Heryanto. (2020). Pinjaman Orang Aceh ke Pinjol Tembuh Rp. 417.6 Miliar. Retrieved Agustus 30, 2021, from https://beritakini.co/news/pinjaman-orang-aceh-ke-pinjol-tembus-rp-417-6miliar/index.html

Embu, W. S., Faqir, A. A., Ronald, \& Sari, H. R. (2021). Mendalami Cara Kerja Pinjaman Online. Retrieved Agustus 30, 2021, from https://www.merdeka.com/khas/mendalami-cara-kerjapinjaman-online-terjerat-utang-online-1.html

Hadiwardoyo, W. (2020). Kerugian Ekonomi Nasional Akibat Pandemi Covid-19. Baskara: Journal of Business and Entrepreneurship, 2(2), 83-92, DOI: 10.24853/baskara.2.2.83-92.

Harian Aceh. (2021). Isi Surat Wasiat Karyawan Bank Perkreditan yang Gantung Diri Terjerat Pinjol. Retrieved Agustus 30, 2021, from https://www.harianaceh.co.id/2021/08/24/isi-surat-wasiatkaryawan-bank-perkreditan-yang-gantung-diri-terjerat-pinjol/

Harian Aceh. (2021). Literasi Keuangan, Upaya Melindungi Konsumen dari Dampak 'Pinjol'. Retrieved Agustus 30, 2021, from https://www.harianaceh.co.id/2021/08/06/literasi-keuangan-upayamelindungi-konsumen-dari-dampak-pinjol/

Hirdianto, S. (2021). Bahaya Dibalik Kemudahan Penggunaan Layanan Pinjaman Online. Retrieved Agustus 29, 2021, from https://itgid.org/bahaya-dibalik-kemudahan-penggunaan-layananpinjaman-onlinel

Husna, M. (2020). Dampak Pandemi Covid 19, Omzet UMKM Turun Hingga 75 Persen. Retrieved Agustus 29, 2021, from https://aceh.tribunnews.com/2020/10/08/dampak-pandemi-covid-19-omzet-umkmturun-hingga-75-persen

Ikhsan, M. (2021). Pinjaman Online Tanpa Agunan di Banda Aceh. Retrieved Agustus 30, 2021, from https://pinjamanonlinecepat.co.id/agunan/pinjaman-online-tanpa-agunan-di-banda-aceh

Kurniawan, F., \& Wijaya, C. (2020). The effect of loan granted factor on peer-to-peer lending (funded loan) in Indonesia. Investment Management and Financial Innovations, 17(4), 165-174. doi:10.21511/imfi.17(4).2020.16.

Mohsin, A., Hongzhen, L., \& Hossein, S. F. (2021). Impact of COVID-19 Pandemic on Consumer Economy: Countermeasures Analysis. Sage Journals, 11(2), https://doi.org/10.1177/21582440211008875.

Nasution, D. A., Erlina, \& Muda, I. (2020). Dampak Pandemi Covid-19 Terhadap Perekonomian Indonesia. Jurnal Benefita, 5(2), 212-224, DOI : 10.22216/jbe.v5i2.5313.

Nurchalish. (2020). Dampak Ekonomi Pandemi Covid-19. Retrieved Agustus 29, 2021, from https://aceh.tribunnews.com/2020/04/25/dampak-ekonomi-pandemi-covid-19?page=2 
Nurhadi, F. (2020). Pinjol Ilegal, Jebak Warga Aceh di Tengah Pandemi. Retrieved Agustus 29, 2021, from https://www.times.id/2020/11/pinjol-ilegal-jebak-warga-acehdi-tengah.html

Otoritas Jasa Keuangan. (2021). Ini Daftar Penyelenggara Pinjaman Online Berizin. Retrieved Agustus 30, 2021, from https://rri.co.id/banda-aceh/ekonomi/1053735/ojk-ini-daftar-penyelenggara-pinjamanonline-berizin

Panginan, E. K., \& Irwansyah. (2020). Fenomena Aplikasi Kredit dan Pinjaman Online Kredivo Di Indonesia. Jurnal Komunikasi dan Kajian Media, 4(1), 12-26, DOI: http://dx.doi.org/10.31002/jkkm.v4i1.1393.

Presilawati, F., Erlinda, E., \& Muhammad, R. (2020). Dampak Dari Virus Covid- 19 Terhadap Perekonomian Masyarakat Kota Banda Aceh. Jurnal Ilmiah Manajemen Muhammadiyah Aceh (JIMMA), 10(2), 103-110, DOI: https://doi.org/10.37598/jimma.v10i2.1005.

Republika. (2021). Bappeda: Covid-19 Ikut Pengaruhi Ekonomi Aceh. Retrieved Agustus 29, 2021, from https://www.republika.co.id/berita/qopt7g384/bappeda-covid19-ikut-pengaruhi-ekonomi-aceh

RRI. (2021). Solusi Penanganan Maraknya Pinjol di Aceh. Retrieved Agustus 30, 2021, from https://rri.co.id/banda-aceh/ragam/1169721/solusi-penanganan-maraknya-pinjol-di-aceh

Safitri, D. (2019). Potensi dan Perkembangan Fintech di Provinsi Aceh. Retrieved Agustus 30, 2021, from https:/duniafintech.com/fintech-di-provinsi-aceh/

Salvasani, A., \& Kholil, M. (2020). Penanganan Terhadap Financial Technology Peer-to-Peer lending Ilegal Melalui Otoritas Jasa Keuangan (Studi Pada OJK Jakarta Pusat). Jurnal Privat Law, VIII(2), 252259, DOI: https://doi.org/10.20961/privat.v8i2.48417.

Samudro, A. I., \& Risha, S. V. (2021). Peer-To-Peer Lending Vs. Commercial Bank'S Credit System: Financing Solutions For MSMEs in Indonesia. The Lawpreneurship Journal, 1(1), 58-81.

Santi, E., Budiharto, \& Saptono, H. (2017). Pengawasan Otoritas Jasa Keuangan terhadap Financial Technology (Peraturan Otoritas Jasa Keuangan Nomor 77/POJK.01/ 2016). Diponegoro Law Journal, 6(3), 1-20.

Santi, M. (2019). Peran Pinjaman Dana Berbasis Online Melalui Aplikasi Terhadap Perekonomian Di Indonesia. Jurnal Eksyar (Jurnal Ekonomi Syariah), 6(2), 116-127.

Satgas Waspada Investasi. (2021). Ada Penurunan Jumlah Blokir Pinjol Ilegal hingga Juli 2021. Retrieved Agustus 30, 2021, from https://teknologi.bisnis.com/read/20210715/84/1418235/swi-adapenurunan-jumlah-blokir-pinjol-ilegal-hingga-juli-2021

Setyadi, A. (2021). Ekonomi Aceh Tumbuh 2,56\%, Terendah di Sumatera? Retrieved Agustus 29, 2021, from https:/finance.detik.com/berita-ekonomi-bisnis/d-5671100/ekonomi-aceh-tumbuh-256terendah-di-sumatera

Sihombing, N. M., Suryanto, N. E., Mahameru, M., Setiawan, M. R., \& Marsella, E. (2019). Dampak Penggunaan Pinjaman Online Terhadap Gaya Hidup Konsumtif Mahasiswa Yogyakarta. Proceeding SINTAK 2019 (pp. 500-507). Unisbank.

Suiter, W. O., \& Thomas, R. G. (1938). Modern Banking. Southern Economic Journal, 5(1), 102. https://doi. org/10.2307/3693817.

Supriyanto, E., \& Ismawati, N. (2019). Sistem Informasi Fintech Pinjaman Online Berbasis Web. Jurnal Sistem Informasi, Teknologi Informasi dan Komputer, 9(2), 100-107, DOI: https://doi.org/10.24853/justit.9.2.100-107.

Susilo, A., Rumende, C. M., Pitoyo, C. W., Santoso, W. D., Yulianti, M., Herikurniawan, H., et al. (2020). Coronavirus Disease 2019: Tinjauan Literatur Terkini. Jurnal Penyakit Dalam Indonesia, 7(1), 4567, DOI: http://dx.doi.org/10.7454/jpdi.v7i1.415.

Syahputra, A., Armayani, R. R., \& Syahmalluddin, L. S. (2020). Pengaruh Covid-19 Terhadap Aktivitas Sosial dan Ekonomi Masyarakat Lhokseumawe. ETNOREFLIKA: Jurnal Sosial dan Budaya, 9(3), 226-237, https://doi.org/10.33772/etnoreflika.v9i3.898.

US DEPARTMENT OF THE TREASURY. (2016). Opportunities and Challenges in Online Marketplace Lending. Washington DC: US DEPARTMENT OF THE TREASURY. 
Wahyuni, R. A., \& Turisno, B. E. (2019). Praktik Finansial Teknologi Ilegal Dalam Bentuk Pinjaman Online Ditinjau Dari Etika Bisnis. Jurnal Pembangunan Hukum Indonesia, 1(3), 379-391.

Wang, P. Z. (2015). Exploring the critical factors influencing online lending intentions. Financial Innovation, 1(8), https://doi.org/10.1186/s40854-015-0010-9.

White House National Economic Council. (2012). Moving America's Small Businesses \& Entrepreneurs Forward: Creating an Economy Built to Last. Retrieved Agustus 30, 2021, from https://www.whitehouse.gov/sites/default/files/docs/small_business_report_05_16_12.pdf

Wibowo, A. \&. (2017). The Strategy of The Banking Industry in Indonesia: Following Institutional Theory or Resource-Based View? Jurnal Siasat Bisnis, 21(2), 131-141. https://doi.org/10.20885/jsb.vol21.iss2.art3. 